\title{
Rehabilitation of Mediterranean dwarf-shrub range- land with herbicides, fertilizers, and fire
}

\author{
Z. HENKIN, N.G. SELIGMAN, I. NOY-MEIR, U. KAFKAFI, AND M. GUTMAN
}

Authors are research scientists with the Galilee Technological Center (MIGAL), Qiryat Shemonah, Israel (Z.H., N.G.S.); Professor, Department of Evolution, Systematics and Ecology, The Hebrew University of Jerusalem, Jerusalem, Israel (I.N-M); Professor, Department of Field Crops, Faculty of Agriculture, The Hebrew University of Jerusalem, Rehovot, Israel (U.K.); and research scientist, Department of Natural Resources, Agriculture Research Organization, The Volcani Center, P.O. Box 6, Bet Dagan, Israel (M.G.)

\section{Abstract}

An experiment was conducted on a Mediterranean hill range dominated by communities of spiny dwarf-shrubs (mainly prickly burnet Sarcopoterium spinosum ( $L$. Spach) in order to determine the effects of $P$ fertilizer application, shrub control and fire on the herbaceous and shrub components of the community. Herbicide (2,4-D) application eliminated almost all the shrubs in the first year and their regeneration was relatively slow: 6 years after the application, shrub cover was less than one-third of what it was at the beginning of the experiment. After fire, regeneration was rapid and original shrub cover was restored within 6 years. A single application of phosphorus fertilizer $\left(4.5-9.0 \mathrm{~g} \mathrm{P} \mathrm{m}^{-2}\right)$ significantly retarded regeneration of shrub cover and produced a three to five fold increase in herbaceous biomass production. The residual effect of the fertilizer application was still significant at the end of the 7-year monitoring period.

The herbaceous vegetation in the P-fertilizer treatments was dominated by annual legume species throughout the experiment. The prolonged response of the herbaceous sward patches to a single $P$ application appeared to be caused by the gradual release of phosphate from the applied fertilizer and also by the summer grazing system that facilitated recycling of soil nutrients on the site. Above-ground biomass on herbaceous sward patches increased not only as a consequence of nutrient amelioration, but also because of reduced competition from the lower shrub cover following fire or herbicide application. Shrub recovery that was dependent on the residual cover in the first year following fire and/or herbicide treatment, was further retarded by competition from the vigorous herbaceous vegetation that benefited from nutrient amelioration. The implications of these results for range improvement depend to a large degree on the economic conditions relevant to the grazing system.

Key Words: range improvement, shrub control, phosphorus, patch productivity, plant community dynamics, Sarcopoterium spinosum

The original experiment was funded by grants from the Northern Israel R\&D, the Jewish National Fund, and the Soil Conservation Division of the Israel Ministry of Agriculture. Continuation of this study was supported by a grant from KFO-BEO, Juelich (Germany), under the cooperative Program in Environmental Research and the Israel Ministry of Science and Arts. Hagit Baram, ARO, The Volcani Center, Bet Dagan, helped with the statistical analyses. Soil and plant analyses were performed at the chemical laboratory of the Galilee Technological Center (MIGAL), Qiryat Shemonah.

This is a contribution from Agricultural Research Organization, Bet-Dagan, No. 1943-E, 1996 series.

Manuscript accepted 15 Mar. 1997.

\section{Resumen}

Un experimento con el objeto de determinar la influencia del fertilizado fosfórico, control de arbustos espinosos por intermedio de herbicidas e incendios controlados fue conducido en un pastizal situado en el Norte de Israel. La vegetación es del tipo Mediterráneo dominada por arbustos espinosos enanos. La aplicación de herbicidas $(2,4, D)$ eliminó practicamente todos los arbustos en el año del tratamiento, siendo la reabilitación de los arbustos relativamente lenta: seis años después del tratmeinto la cobertura de los arbustos era inferior en un tercio en comparación con la cobertura antes del tratamiento. Despues de un incendio controlado la recuperación es rápida tardando seis años para alcanzar la cobertura original. Aplicación de fertilizante fosfórico (4.5-9.0 $\left.\mathrm{g} \mathrm{Pm}^{-2}\right)$ retardó en forma significante la regeneración arbustiva incrementando la próducción herbácea entre $300 \%$ y $500 \%$ en. El effecto residual del fertilizante seguía siendo significante siete años después de una única aplicación.

La vegetación herbácea en las parcelas fertilizadas estaba dominada por leguminosas anuales durante toda la experiencia. La respuesta prolongada de la vegetación a una única aplicación de fertilizante es adjudicada a la liberación gradual del fosfato contenido en el fertilizante aplicado y a el systema de pastoreo conducido durante lá estación seca estival que permitió el reciclamiento de los nutrientes en el lugar. La biomasa herbácea subperficial incrementó no solo a consecuencia de la fertilización sino por la disminución de la competencia causada por arbustos enanos depues de un incendio controlado o la aplicación de herbicidas. La recuperación de los arbustos, que depende de la cobertura residual en el primer año despues del tratamiento (herbicida o fuego), fué adicionalmente retardada por la competencia con la vegetación herbácea que se benefició debido a la fertilización. La implementación de los resultados en la mejoracón de pasturas dependerá de las condiciones económicas de cada sistema de pastoreo.

Dwarf-shrub communities dominated by prickly burnet (Sarcopoterium spinosum (L.) Spach) cover large areas of hilly rangeland in eastern Mediterranean regions (Zohary 1973). Pasture and animal production in these areas is low because of the sparse cover of herbaceous vegetation and the low palatability of prickly burnet. On terra rossa and brown rendzina soils, herbaceous primary production is low mainly because of phosphorus (P) deficiency (Rabinovich-Vin 1979, Henkin et al. 1994). 
However, it has been shown that despite the degraded appearance of these rangelands (Naveh and Dan 1973), the sites can be rehabilitated and converted to much more productive pasture. The necessary measures include shrub control with firc, herbicides, nutrient amelioration and grazing management (Ofer and Seligman 1969; Naveh 1988; Osman et al. 1991; Henkin et al. 1994).

Stability of conversion in the long run depends to a large degree on the resilience of the shrubs and the vigor of the herbaceous sward. Consequently, the persistence of an intervention and the need for maintenance of a desirable range condition is dependent on the complex dynamics of the constituent biotic and abiotic elements of the system. There are very few long-term studies of this aspect of vegetation manipulation in Mediterranean dwarfshrub ecosystems. Better understanding of the influence of anthropogenic interventions on such ecosystems is necessary to guide their management for forage production, fire control, conservation and recreation. The main objective of the present study was to determine the intensity and persistence of the effects of shrub control and a single application of $P$ fertilizer on forage production and shrub cover. It summarizes a controlled vegetation conversion experiment that has been monitored continuously for 7 years.

\section{Materials and Methods}

\section{Study Site}

The study site is located near En Yaaqov, $15 \mathrm{~km}$ east of the Mediterranean coastline in western Galilee, Israel (long. $35^{\circ} 15^{\prime} \mathrm{E}$; lat. $33^{\circ} 01 ' \mathrm{~N}$; alt. $500 \mathrm{~m}$ ). The average seasonal precipitation is $780 \mathrm{~mm}$, with large inter- and intra-seasonal variation; during the years of this study, it ranged between 569 and $1,328 \mathrm{~mm}$. The growing season of the herbaceous vegetation begins between October and December and ends between April and May of the following year. Data referring to any season will be identified by the year in which the growing season ended, i.e., 1988/89 will be written as 1989. The soil is a 'terra-rossa', Xerochrepts, Haploxeroll (Dan et al. 1975; Soil Survey Staff 1975) overlying Turonian hard limestone. Concentration of bicarbonate soluble $\mathrm{P}$ ('available P') in the top $3 \mathrm{~cm}$ soil layer is commonly less than 6 $\mathrm{mg} \mathrm{kg}{ }^{-1}$. The rangeland is a typical Mediterranean 'batha' vegetation, dominated by prickly burnet dwarf-shrubs (Zohary 1973). Patches of deeper soil (sometimes down to $50 \mathrm{~cm}$ ) are interspersed between rock outcrops, some of it on abandoned terraces. The terraces have not been cultivated for at least 45 years but the area has been grazed heavily by goats. Since 1986 only beef cattle have grazed on the site, from the end of the growing season in spring and throughout the dry summer. The study was conducted on this area in an exclosure protected from grazing during the winter/spring growing season.

\section{Experimental design}

This study included 2 experiments to evaluate the effect of shrub control (with herbicides and fire) and a single application of phosphorus fertilizer on long-term pasture productivity and shrub cover. Experiment ' $A$ ' was not burned throughout the study while Experiment ' $B$ ' was burned after the application of the treatments. In both experiments, monitoring of shrub cover and peak biomass production in the sward patches between the shrubs began in the season prior to the implementation of the treatments. Experiment ' $A$ ' was begun one year later than Experiment 'B', but will be treat- ed first because it was the smaller and simpler experiment and represents the initial condition of the system without burning.

Experiment 'A' was established in 1989 on an unburned area dominated by prickly burnet. It included a single application of $4.5 \mathrm{~g} \mathrm{P} \mathrm{m}^{-2}$ with shrub control $\left(\mathrm{P}_{4.5} \mathrm{H}_{\mathrm{E}}\right)$ and without it $\left(\mathrm{P}_{4.5} \mathrm{H}_{0}\right)$, as well as a control $\left(\mathrm{P}_{0} \mathrm{H}_{0}\right)$. In the spring of 1989 , shrubs were sprayed to runoff with $2,4-\mathrm{D}$ as $1 \%$ acid equivalent in aqueous solution with a manually operated sprayer. In October 1989, P fertilizer was applied as enriched super phosphate $\left(25 \% \mathrm{P}_{2} \mathrm{O}_{5}\right)$ spread by hand on the surface. In October 1994, P fertilizer was applied a second time at the same rate as previously on both $P_{4.5}$ treatments. The plots in this experiment were $5 \times 5 \mathrm{~m}$ and the treatments were randomized in 5 replicated blocks. There were three treatment combinations in experiment ' $\mathrm{A}$ ', as follows:

\begin{tabular}{ccc}
\hline \hline Herbicide & \multicolumn{2}{c}{ Phosphorus fertilization } \\
\cline { 2 - 3 } treatment & Control & $4.5 \mathrm{~g} \mathrm{P} \mathrm{m}^{-2}$ \\
& $\left(\mathrm{P}_{0}\right)$ & $\left(\mathrm{P}_{4.5}\right)$ \\
\hline Control $\left(\mathrm{H}_{0}\right)$ & $\mathrm{P}_{0} \mathrm{H}_{0}$ & $\mathrm{P}_{4.5 \mathrm{H}_{0}}$ \\
Spring $1989\left(\mathrm{H}_{\mathrm{E}}\right)$ & & $\mathrm{P}_{4.5} \mathrm{H}_{\mathrm{E}}$ \\
\hline
\end{tabular}

Experiment ' $\mathbf{B}$ ' was established in 1988 on an adjacent area also dominated by prickly burnet. The whole area was accidentally burnt in the summer (July) of 1988. Shrub control by application of selective herbicide (2,4-D) sprays was implemented as two separate treatments, one in April 1988 before the fire (early, $\mathbf{H}_{E}$ ) and another in April 1990 on the regrowth 2 years after the burn (late, $\left.H_{L}\right)$. $P$ fertilizer treatments $\left(P_{4.5}, P_{9.0}\right)$ at 2 rates $(4.5$ and $9.0 \mathrm{~g} \mathrm{P} \mathrm{m}^{-2}$, respectively) were applied in the autumn of 1988 as a single application of enriched super phosphate spread by hand. The treatments were applied to $10 \times 10 \mathrm{~m}$ plots allocated at random in 5 replicated blocks. There were 7 treatment combinations in experiment ' $B$ ', as follows:

\begin{tabular}{lllll}
\hline \multirow{2}{*}{$\begin{array}{c}\text { Herbicide } \\
\text { treatment }\end{array}$} & & \multicolumn{3}{c}{ Phosphorus fertilization } \\
\cline { 3 - 5 } & & \multicolumn{4}{c}{ Control } & $4.5 \mathrm{~g} \mathrm{P} \mathrm{m}^{-2} 9.0 \mathrm{~g} \mathrm{P} \mathrm{m}^{-2}$ \\
\hline & $\left(\mathrm{P}_{0}\right)$ & $\left(\mathrm{P}_{4.5}\right)$ & $\left(\mathrm{P}_{9.0}\right)$ \\
Control & $\left(\mathrm{H}_{0}\right)$ & $\mathrm{P}_{0} \mathrm{H}_{0}$ & $\mathrm{P}_{4.5} \mathrm{H}_{0}$ & $\mathrm{P}_{9.0} \mathrm{H}_{0}$ \\
Pre-burn,spring 1988 & $\left(\mathrm{H}_{\mathrm{E}}\right)$ & $\mathrm{P}_{0} \mathrm{H}_{\mathrm{E}}$ & $\mathrm{P}_{4.5} \mathrm{H}_{\mathrm{E}}$ & \\
2yr post-burn, spring 1990 $\left(\mathrm{H}_{\mathrm{L}}\right)$ & $\mathrm{P}_{0} \mathrm{HL}$ & $\mathrm{P}_{4.5} \mathrm{H}_{\mathrm{L}}$ & \\
\hline
\end{tabular}

\section{Plant and soil variables}

Peak above-ground biomass on herbaceous sward patches between the shrubs and rocks, was sampled in April at the end of each growing season. A $25 \times 25 \mathrm{~cm}$ quadrat was randomly placed on a herbaceous patch and shoot biomass was harvested down to ground level; the procedure was repeated 5 times in each plot. The harvested plant material was oven-dried at $75^{\circ} \mathrm{C}$, weighed, and ground for subsequent chemical analysis.

Botanical composition was determined before harvest by visually scanning each of the $25 \times 25 \mathrm{~cm}$ sample quadrats to estimate the relative cover of grass, legumes and forbs in the area defined by the quadrat. The botanical composition of the plot was the average estimated composition of the five sample quadrats in each plot. Annual species dominated the herbaceous vegetation. The most common species were:

Legumes (annual) Trifolium stellatum L., Trifolium pilulare Boiss., Trifolium campestre Schreber, Trifolium purpureum Loisel., Medicago polymorpha L., Medicago rotata Boiss., Scorpiurus muricatus L., Hymenocarpos circinnatus L. Savi. 
Forbs (annual) Plantago cretica L., Linum spp., Hedypnois cretica (L.) Dum.-Courset, Crepis aspera L.

Grasses (annual) Crithopsis delileana (Schultes et Schultes fil.) Roshev., Aegilops peregrina (Hackel) Maire et Weiller, Bromus spp., Avena sterilis L.

Grasses (perennial) Hordeum bulbosum L., Dactylis glomerata L., Piptatherum blancheanum Boiss., Andropogon distachyos L.

(Botanical nomenclature according to Feinbrun-Dothan and Danin 1991).

Cover components. The relative cover of rock outcrops, canopy cover of prickly burnet shrubs, other woody vegetation, and soil patches without shrub cover was estimated each year in each plot by recording the component that lay vertically under each of 100 points arranged as 10 rows, each with 10 points. The rows and each point were spaced at $40 \times 40 \mathrm{~cm}$ in experiment ' $A$ ' and at $90 \times 90 \mathrm{~cm}$ in experiment ' $B$ '. Rock covered by shrub canopy or by herbaceous vegetation was recorded as 'rock'. The herbaceous vegetation that grew on the soil patches was composed predominantly of annual species and tended to form a closed canopy in all treatments towards the end of the growing season. Consequently, cover of herbaceous vegetation canopy was regarded as equivalent to cover of soil patches.

Soil sampling and analysis. Before fertilizer application and at the end of each growing season, soil samples from depths of 0 $3 \mathrm{~cm}$ and $3-15 \mathrm{~cm}$ were taken from all treatments. In each plot, soil from 3 randomly placed auger holes was pooled for analysis. Available $P$ in the soil was measured by extraction with $0.5 \mathrm{M}$ Na-bicarbonate at pH 8.5 (Olsen et al. 1954).

\section{Patches and communities}

The vegetation cover in the dwarf shrub community on the area not covered by bare rock, was subdivided into herbaceous sward canopy (composed predominantly of annual species), prickly burnet and other woody species. Samples of herbaceous biomass were taken from quadrats placed on sward patches between the shrubs. They reflect the influence of treatments on the productivity of the herbaceous sward, but not on the relative areas of shrub and herbaceous sward cover. Community response includes also the treatment effect on shrub cover and the consequent effect on herbaceous sward area within the community. Herbaceous aboveground biomass production on a community basis, $\mathrm{C}$, was calculated as:

$$
\mathrm{C}=\mathrm{Y}\{1-(\mathrm{S}+\mathrm{R}+\mathrm{W})\}
$$

where,

$\mathrm{C}, \mathrm{Y}=$ Herbaceous biomass dry matter in the community and in sward patches, respectively $\left(\mathrm{g} \mathrm{m}^{-2}\right)$

$S, R, W=$ Relative cover of prickly burnet shrubs, rocks and other woody species, respectively (0-1)

The relative cover of rocks and other woody species within plots varied very little between years and averaged $20.5 \%$ and $1.5 \%$, respectively. Consequently, $\mathrm{C}$ was essentially a function of $\mathrm{Y}$ and $\mathrm{S}$.

\section{Statistical Analysis}

Fertilizer and shrub control effects and their interactions for each year as well as for all years combined (including a 'year' effect), were analyzed with the SAS general linear model (GLM) procedure (SAS 1985), to estimate overall significance of treat- ment effects in a multifactor model. The CONTRAST procedure (SAS 1985) was used to estimate significance of differences due to herbicide or fertilizer effects on patch biomass, community biomass and shrub cover. The following GLM models were used for analysis of variance:

\begin{tabular}{lcc}
\hline Source & $\begin{array}{c}\text { Experiment } \\
\text { 'A' }\end{array}$ & $\begin{array}{c}\text { Experiment } \\
\text { 'B' }\end{array}$ \\
\hline & (Degrees of freedom) & \\
Treatment & 2 & 6 \\
Year & 5 & 5 \\
Block & 4 & 4 \\
Treat $\times$ Year & 10 & 25 \\
Treat $\times$ Block & 8 & 20 \\
Error & 60 & 149 \\
Total & 89 & 209 \\
\hline
\end{tabular}

\section{Results}

\section{Experiment ' $\mathbf{A}$ '}

In experiment ' $A$ ', where the shrubs were not burnt, the average above-ground biomass in sward patches in the control treatment $\left(\mathrm{P}_{0} \mathrm{H}_{0}\right)$ was only $74 \mathrm{~g} \mathrm{~m}^{-2}$ dry matter. Fertilizer application had a highly significant positive effect on biomass production of herbage patches (Fig. 1a). The additional positive effect of shrub control on herbage production in patches was consistent, but generally not significant in any 1 year. However, the overall effect over 6 years was significant (Table 1). The increase in production achieved in 1995 following a second application of $\mathrm{P}$ fertilizer was only partly the result of the second $P$ application, because a similar increase was recorded in experiment ' $B$ ' (see below), where no extra $P$ was added (Fig. 2a).

Table 1. Observed significance levels of mean 6-year effect with $\left(\mathbf{P}_{4.5}\right)$ and without $\left(\mathbf{P}_{0}\right)$ fertilizer application and with $(\mathrm{HE})$ and without $(\mathbf{H} 0)$ shrub control on vegetation responses in Experiment ' $A$ ' (without burning the shrubs); tested by orthogonal contrasts ${ }^{1}$.

\begin{tabular}{lcc}
\hline \hline & \multicolumn{2}{c}{ Contrasts } \\
\cline { 2 - 3 } Vegetation response & $\mathrm{P}_{0}$ vs $\mathrm{P} 4.5$ & $\mathrm{H}_{0} \mathrm{vs} \mathrm{H}_{\mathrm{E}}$ \\
\hline & - (significance level, $\mathrm{p}<$ ) - \\
Yield in patches & 0.0001 & 0.0287 \\
Yield in community & 0.0009 & 0.0001 \\
Shrub cover & 0.0003 & 0.0001 \\
\hline
\end{tabular}

by CONTRAST procedure (SAS 1985).

Application of herbicide reduced the cover of shrubs (Fig. 1b) and this effect remained highly significant $(\mathrm{P}<0.0001)$ throughout all 6 years of the experiment. The negative effect of fertilizer application on shrub cover, even though not significant in all years, was highly significant when analyzed over the 6 years of the study (Table 1).

The difference between the patch and the community response was caused by differences in shrub cover, which was reduced mainly by control with herbicide and to a lesser extent following fertilizer application, probably by greater competition from the herbaceous vegetation. 


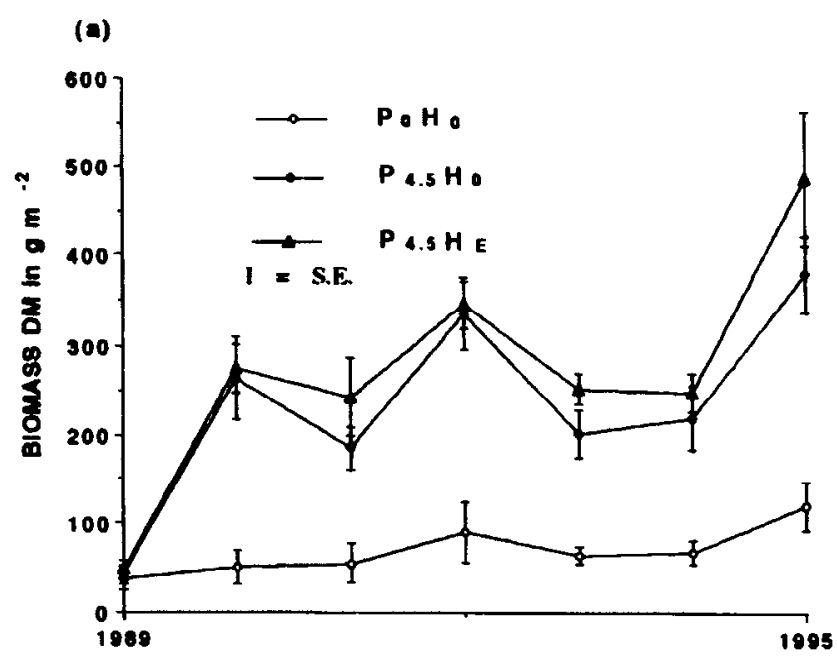

(b)

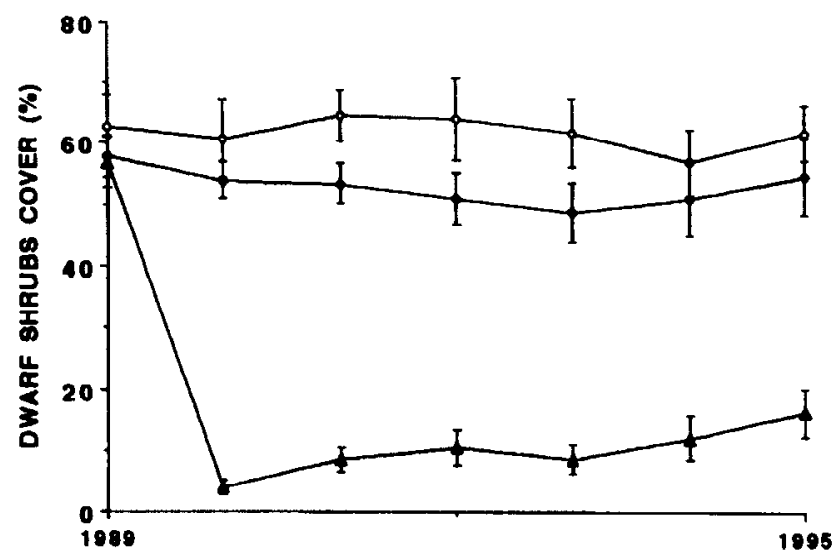

Fig. 1. Experiment 'A': Annual peak herbaceous biomass and shrub cover undisturbed by fire throughout the duration of the experiment; P fertilizer - $4.5 \mathrm{~g} \mathrm{P} \mathrm{m}^{-2}$ - applied in October 1989 and again in October 1994; shrub control - 2,4-D - in April 1989. (a) Peak herbaceous biomass in sward patches. (b) Cover of dwarf shrubs.

\section{Experiment ' $B$ '}

Above-ground herbaceous biomass in sward patches. In the control $\left(\mathrm{P}_{0} \mathrm{H}_{0}\right)$ plots, the transient increase in herbaceous biomass in the first 2 years after the fire may have been related to higher nutrient availability following the fire. After the fire, in all years, biomass production of the herbaceous patches following application of $\mathrm{P}$ was significantly $(\mathrm{P}<0.0001)$ higher than that in the control plots (Fig. 2a). The magnitude of the $\mathbf{P}$ effect was greatest in the second year but remained high even in the seventh year. Compared to the control treatment, the relative increase in production following $\mathbf{P}$ application was more or less constant throughout the experiment: in the $\mathrm{P} 4.5 \mathrm{HO}$ treatment it varied between a 2.9 fold increase in the second year and 3.1 fold increase in the seventh, and in the $\mathrm{P}_{90} \mathrm{H}_{0}$ treatment production stayed between 3.5 to 4.2 times higher than in the control throughout the seven years.

The herbaceous biomass production following an application of double the amount of fertilizer $\left(\mathbf{P}_{9.0}\right)$, was higher than at the single level during all 7 years of the experiment. The significance level varied from $P=0.0451$ to 0.0001 . However, the quantitative effect of the extra $4.5 \mathrm{~g} \mathrm{P} \mathrm{m}^{-2}$ was much smaller than that of the first $4.5 \mathrm{~g} \mathrm{P} \mathrm{m}^{-2}$ (0.34-0.79 times the effect of the initial amount).

Shrub control by herbicide application before the fire $\left(\mathrm{H}_{\mathrm{E}}\right)$ significantly increased herbaceous biomass in the sward patches in every year (Fig. 2a), from the second year after the treatment $(P<0.05)$ until the seventh year $(P<0.01)$. Over all years there was a significant $(\mathrm{P}<0.0124)$ interaction between $\mathrm{H}$ and $\mathrm{P}$. The average relative increase due to herbicide was larger in the $\mathrm{P}_{0}$ treatment $(80 \%)$ than in the $\mathrm{P}_{45}$ treatment (10\%) (Table 2). In the first year after application, the herbicide treatment actually reduced biomass in the $P_{4.5}$ treatment and generated a significant $(P<0.0124)$ interaction between $\mathrm{H}$ and $\mathrm{P}$. In all subsequent years herbicide resulted in a small additional increase of biomass in the herbaceous patches of the $\mathrm{P}_{45}$ plots (Fig. 2a).

The overall effect of herbicide application after the fire (HL) was not significantly different $(P>0.05)$ from application before the fire in any 1 year and also not in the 7-year average (Table 2).

Table 2. Experiment 'B': Seven-year treatment averages and interannual variation of herbaceous biomass production (dry matter) per unit of herbaceous patch between the shrubs $\left(\mathrm{g} \mathrm{m}^{-2} \pm\right.$ S.D. $)$.

\begin{tabular}{lccc}
\hline \hline $\begin{array}{l}\text { Herbicide } \\
\text { treatment }\end{array}$ & \multicolumn{3}{c}{ Fertilizer treatment $^{1}$} \\
\cline { 2 - 4 } $\mathrm{P}_{0}$ & $\mathrm{P}_{4.5}$ & $\mathrm{P}_{9.0}$ \\
$\mathrm{H}_{0}$ & $109 \pm 38.4$ & $282 \pm 99.2$ & $383 \pm 118.1$ \\
$\mathrm{H}_{\mathrm{E}}$ & $181 \pm 49.6$ & $310 \pm 116.1$ & - \\
$\mathrm{H}_{\mathrm{L}}$ & $186 \pm 61.4$ & $349 \pm 111.6$ & - \\
\hline
\end{tabular}

${ }^{1}$ See text: Experimental design.

Shrub cover. The original relative cover of prickly burnet at the beginning of the experiment was between $50 \%$ and $60 \%$ and was reduced by fire to practically zero. The cover of prickly burnet dwarf shrubs that resprouted or germinated after the fire was significantly lower $(P<0.0001)$ following herbicide application even in the seventh year after treatment (Fig. 2b). Shrub recovery was significantly reduced by $P$ fertilization from the third year $(P<0.05)$ until the sixth year $(P<0$.01) after the treatment, also in treatments without herbicide $\left(\mathrm{H}_{0}\right)$. Seven years after the treatment, shrub cover in control $\left(\mathrm{P}_{0} \mathrm{H}_{0}\right)$ plots had returned to the pre-fire level $(52 \%)$, while in herbicide-treated plots $\left(\mathrm{H}_{E}, \mathrm{H}_{\mathrm{L}}\right)$ it reached only $22 \%$ without $P$, and $14 \%$ with $P$ fertilizer application $\left(\mathrm{P}_{4.5} \mathrm{H}_{\mathrm{E}}\right)$.

Above-ground herbaceous biomass in the community. Fertilizer alone and herbicide application alone had a similar effect on biomass production on a community basis (Fig. 2c), especially after 1991 when shrub cover increased to a greater degree in the $\mathrm{P}_{45} \mathrm{H}_{0}$ treatment than in the $\mathrm{P}_{0} \mathrm{H}_{\mathrm{E}}$ treatment (Fig. $2 b)$. When both fertilizer and herbicide were applied $\left(\mathrm{P}_{4.5} \mathrm{H}_{\mathrm{E}}\right)$, the differences in biomass production between treatments were greater on a community basis than on a patch basis because the area of patches of herbaceous plants was increased by shrub control and $\mathrm{P}$ application (Fig. 2c). The 7-year average community biomass of herbaceous vegetation in the combined P-fertilizer and herbicide-application plots was 5 times greater than in the control plots (Table 3).

Legume component of the sward. A single application of phosphorus fertilizer had a large and persistent effect on the botanical composition of the herbaceous vegetation. Indigenous 


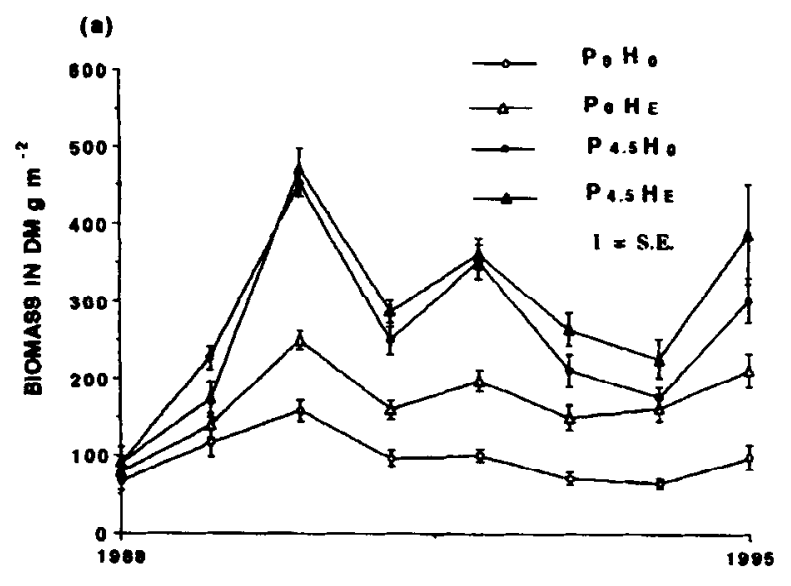

(b)
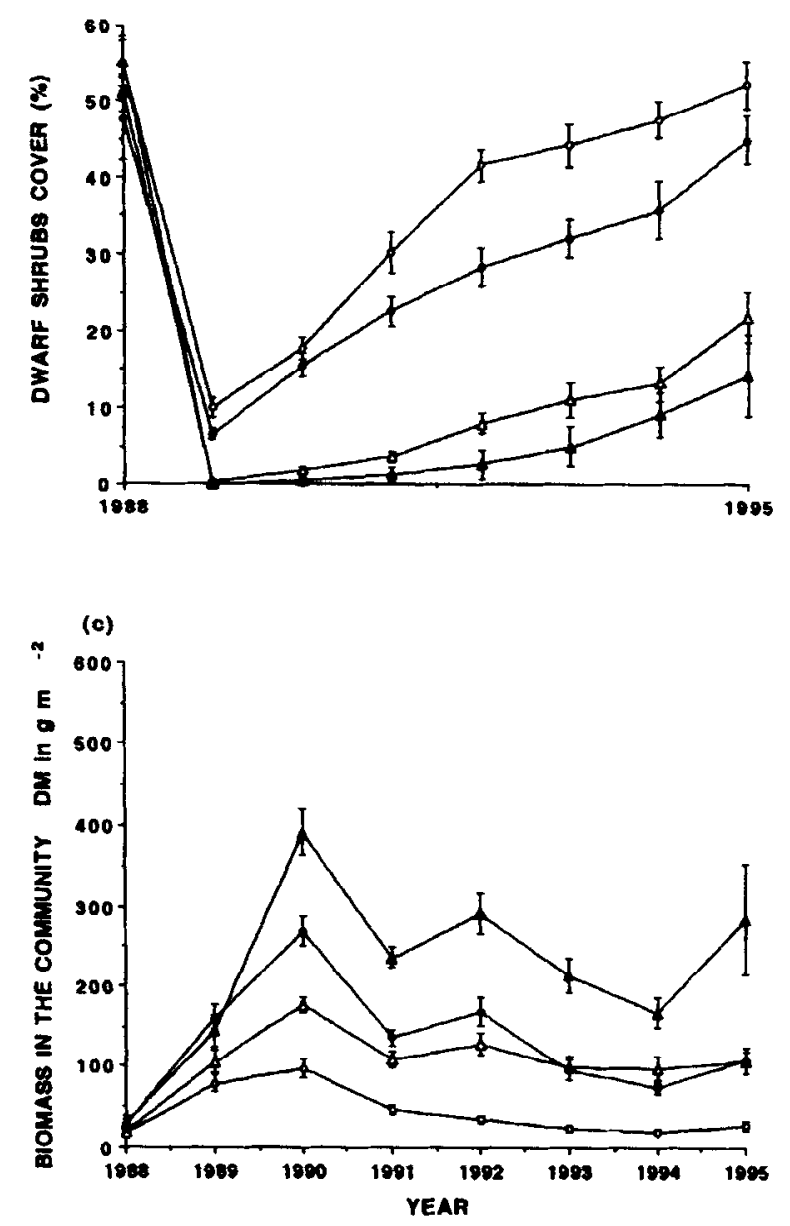

Fig. 2. Experiment ' $B$ ': Response of plant community components to treatments after fire in the summer of 1988. (a) Response of herbaceous biomass on sward patches to $\mathbf{P}$ fertilizer $\left(\mathbf{P}_{4.5}\right)$ applied in October 1988 and to shrub control by selective herbicide application in April $1988\left(\mathrm{H}_{\mathrm{F}}\right)$. (b) Cover of Sarcopoterium spinosum dwarf-shrubs before and after treatment with selective herbicide in April $1988\left(\mathrm{H}_{\mathrm{E}}\right)$ and $\mathrm{P}$ fertilizer application in October 1988 $\left(\mathbf{P}_{4.5}\right)$. (c) Community response of herbaceous biomass to fertilizer and shrub control treatments.
Table 3. Experiment 'B': Seven-year treatment averages and interannual variation of herbaceous biomass production (dry matter), calculated on a plant community basis $\left(\mathrm{g} \mathrm{m}^{-2} \pm\right.$ S.D.).

\begin{tabular}{lccc}
\hline Herbicide & \multicolumn{3}{c}{ Fertilizer treatment $^{1}$} \\
\cline { 2 - 4 } treatment $^{1}$ & \multicolumn{1}{c}{$\mathrm{P}_{0}$} & $\mathrm{P}_{4.5}$ & $\mathrm{P}_{9.0}$ \\
\hline & $-\cdots \cdots$ & $145 \pm 66.7$ & $217 \pm 86.0$ \\
$\mathrm{H}_{0}$ & $47 \pm 31.3$ & $\left.\mathrm{~g} \mathrm{~m}^{-2}\right) \cdots \cdots$ & - \\
$\mathrm{H}_{\mathrm{E}}$ & $118 \pm 38.1$ & $247 \pm 103.0$ & - \\
$\mathrm{H}_{\mathrm{L}}$ & $122 \pm 55.7$ & $247 \pm 93.0$ & - \\
\hline
\end{tabular}

${ }^{1}$ See text: Experimental design.

annual legume species that constituted only $10-20 \%$ of the herbaceous vegetation in unfertilized treatments, following the $P$ application dominated the herbaceous vegetation until the end of the experiment, although there were considerable interannual fluctuations (Fig. 3a). The 2,4-D herbicide applications reduced the legume cover in the year of application but dominance was reestablished in the following year.

\section{Change in soil phosphorus}

At the end of the first growing season, the 'available' $P$ concentration in the top soil layer $(0-3 \mathrm{~cm})$ increased significantly $(P<$ 0.0001 ) from less than $5 \mathrm{mg} \mathrm{kg}^{-1}$ to $30-70 \mathrm{mg} \mathrm{kg}^{1}$ in the $P$ fertilizer treatments (Fig. 3b). The concentration of 'available' $P$ in the top soil layer level in the $P$ treatments decreased with time but remained significantly $(P<0.01)$ higher than in the controls until the 5th year of the experiment. Variability between replications increased with time and differences were not significant in 1994. A similar trend was found at the $3-15 \mathrm{~cm}$ depth, but in this soil layer the level of 'available' soil $P$ was much lower in all treatments than in the top soil layer and differences were not significant in most years.

\section{Discussion}

\section{Forage production}

In this experiment, prickly burnet dwarf-shrub communities with low forage value were converted to highly productive herbaceous communities by combined shrub control (with 2,4-D) and $P$ fertilizer application, either with or without previous burning. The effects of these treatments were maintained for over 6 years after a single application of fertilizer and selective herbicide. Phosphate nutrition was also the key to raising long-term pasture productivity in another study on a similar P-deficient soil (Henkin et al. 1996). The increase in high quality forage opened up practical options for vegetation management in this type of community. Over 7 years, application of $4.5 \mathrm{~g} \mathrm{P} \mathrm{m}^{-2}$ (as super phosphate fertilizer) produced $686 \mathrm{~g} \mathrm{~m}^{-2}$ forage DM or $152 \mathrm{~g}$ of forage DM per $\mathrm{g}$ applied $P$. The shrub control treatment alone produced an increase of $490 \mathrm{~g} \mathrm{~m}^{-2}$ forage DM and the combined treatment produced $1400 \mathrm{~g} \mathrm{~m}^{-2}$ forage DM above control, i.e., more than the combined separate effects, indicating a synergistic interaction between the 2 treatments.

\section{Long term residual effect of a single $P$ fertilizer application}

Seven years after $P$ application, soil-'available' $P$ extracted by the bicarbonate method (Olsen et al. 1954) was still relatively high in the upper $3 \mathrm{~cm}$ of the soil (Fig. $3 \mathrm{~b}$ ). The low solubility of 


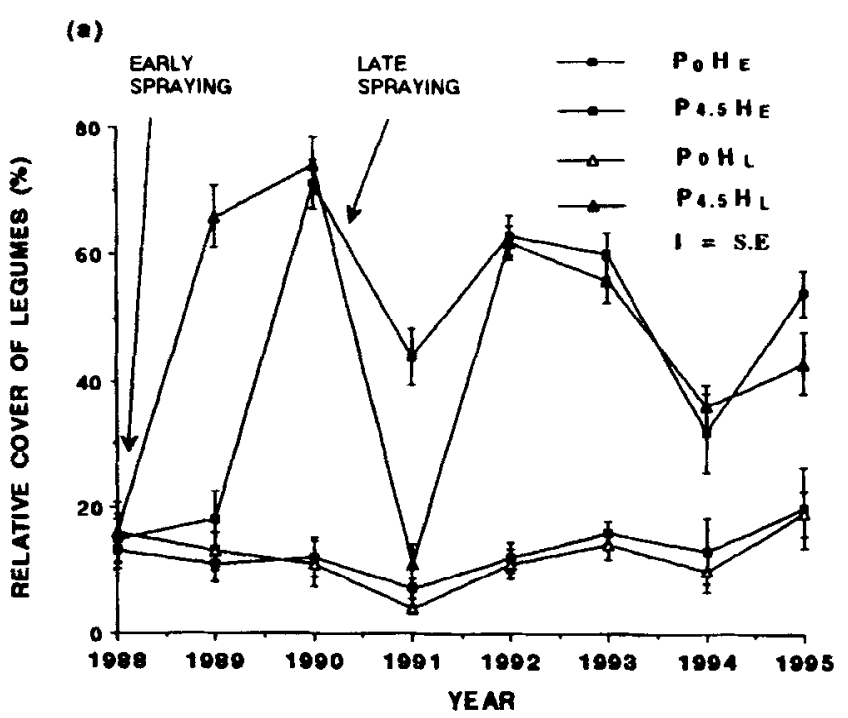

(b)

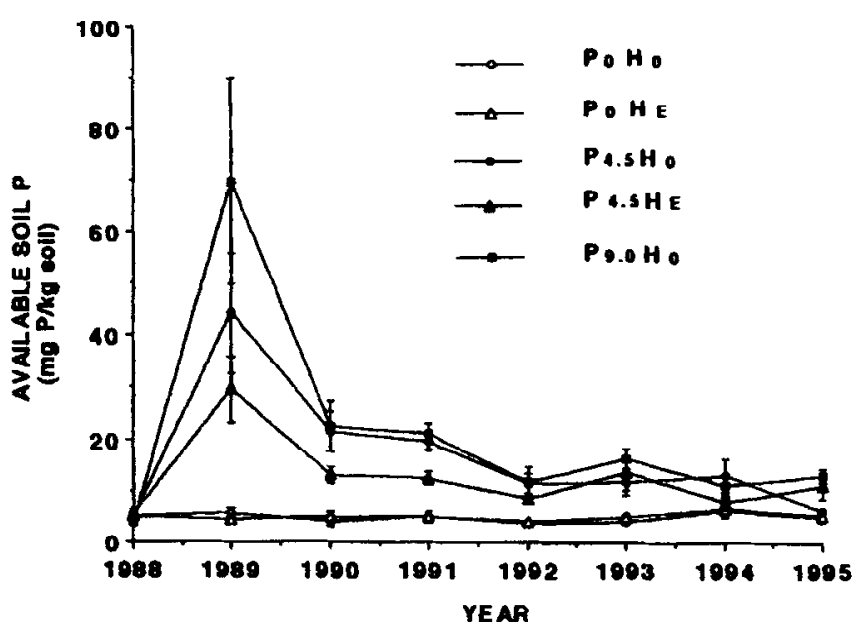

Fig. 3. Experiment ' $B$ ': Legume dominance and 'available' soil $P$ after fire in the summer of 1988 . (a) Relative cover of annual legume species on herbaceous patches before and after treatment with selective herbicide in April $1988\left(\mathrm{H}_{\mathrm{F}}\right)$ or in April $1990\left(\mathrm{H}_{\mathrm{L}}\right)$, and $P$ fertilizer application in October 1988. (b) Effect of a single application of $P$ fertilizer and cattle grazing on 'available' $P$ in the $0-3 \mathrm{~cm}$ soil layer ( $P$ extraction with bicarbonate).

adsorbed $P$ and its gradual release into the soil solution (Fresco et al. 1984) are possibly the main reasons for the 'priming effect' of a single $P$ fertilizer application throughout the experiment. Nutrient enhancement could also have been caused by cattle grazing more intensively on the productive plots (as indicated by the greater density of dung pads). This effect would be amplified by the fact that the poultry litter, given as a non-protein $\mathrm{N}$ supplement (Tagari et al. 1976; Holzer et al. 1986) to the beef cattle grazing the area during summer, was also a rich source of $P$. Another possible $P$ carry-over mechanism could be the greater seed production and consequently greater $P$ storage and recycling in the P treatments. Seed production of the herbaceous species was not measured. Greater seed production following $P$ fertilizer application can be inferred from the observation that the biomass production reached its peak only in the second year after applica- tion of the fertilizer, apparently because of low seed stocks of annual legume species in the first year. The residual effect of a single application of $P$ fertilizer on available $P$ in the soil was not as great as the residual effect on herbage production, possibly because the ability of the plants to extract fertilizer $P$ from the soil was not estimated precisely by the extraction method of available $P$.

\section{Legume dominance}

Following $\mathrm{P}$ fertilizer application, annual legumes dominated the botanical composition of the herbaceous vegetation, falling below 40\% relative cover only in 1994 (Fig. 3a). Such dominance in Mediterranean swards is uncommon. Dominance in 1 year and the consequent $\mathrm{N}$ enrichment of the soil are commonly followed by increase of non-legume nitrophilous species (Rossiter 1966; Olea et al. 1989). Possible reasons for the persistent dominance of leguminous species in this experiment can only be speculated upon at this stage. One hypothesis could be that $\mathrm{N}$ fixation in the poor terra rossa soils is low because local rhizobia have become relatively inefficient as an adaptation to the prevalent low fertility levels (Bottomley and Jenkins 1983; Dowling and Broughton 1986; Materon 1991). In such a case, $N$ fixation could be adequate for the growth of the legume species but because of $\mathrm{N}$ translocation and conservation in the seeds, very little surplus for $\mathbf{N}$ enrichment remains to boost the non-leguminous species. An alternative hypothesis is that in the first 2 years, a large seed stock of legume species was established that was maintained and enlarged in subsequent years both by new seed crops and longterm viability, reinforced by hard-seededness (Rossiter 1966). Abundant germination and consequent competitive pressure could then have suppressed the non-leguminous species. The continued dominance of the legume component deserves more study as both these hypotheses are only speculative.

\section{Shrub resilience}

The recovery rate of the shrub cover was dependent on the residual cover in the year following control with fire and/or herbicide (Fig. 2b). Fire drastically reduced cover, but many plants survived and regrew from root stocks so that already in the first year after the fire, shrub cover was relatively high. Shrub mortality in the herbicide treatment was high and recovery was dependent to a great extent on re-establishment from seeds. Prickly burnet seedling establishment is sensitive to competition for early summer moisture from annual species (Litav et al. 1963), especially when growth of annual species is stimulated by nutrient enhancement. Consequently, resilience of shrub recovery was dependent on whether the main basis for cover increase was relatively rapid expansion from established root stocks or much slower recolonization from seedlings.

\section{Interannual production variability and management implications}

The variability of biomass production between years, expressed as C.V., was relatively constant between treatments and varied from 0.27 to 0.38 . As a consequence, the S.D. was much higher as productivity increased with the addition of P (Tables 2 and 3), with important implications for management of livestock nutrition. This can involve greater risk when stocking rate is set to exploit the greater production. Where feed supplementation is 
feasible, the full benefit of higher productivity can be captured, but at the cost of greater supplementation costs to make up the shortfall in less productive years.

\section{Grazing management and conversion stability}

Interactions between livestock and vegetation are inherent in any grazing system and the grazing management in this experiment certainly influenced the results. Deferment of grazing until the end of the growing season allowed full expression of the treatments on the vegetation, but at a cost of forage quality to the livestock and the need to supply alternative feed sources during the winter-spring grazing season. In addition, summer grazing with some poultry litter supplementation probably enhanced nutrient cycling on the range, especially in the more productive plots following shrub control and fertilization with phosphorus. Consequently it cannot be taken for granted that a similar level of conversion stability would be possible under a winter/spring grazing system where most of the herbaceous biomass would be utilized during the active growing season. However, many of the benefits could be maintained under careful management, especially if a degree of flexibility could be introduced by integration with other pasture or supplementary feed resources. The long residual effect of $\mathbf{P}$ priming under the conditions of this experiment does suggest feasible and prudent improvement strategies that allow for gradual adaptation of the system to a higher level of productivity. The economics of range improvement are complex, but as a rough indication of feasibility under conditions similar to those at the experiment site, the total cost of applying $1 \mathrm{~kg}$ $P$ should be no more than the value of $152 \mathrm{~kg}$ of usable forage dry matter.
Materon, L.A. 1991. Symbiotic characteristics of Rhizobium meliloti in west Asian soils. Soil Biol. Biochem. 23:429-434.

Naveh, Z. 1988. Mediterranean Europe and East Mediterranean shrublands, p. 93-117. In: C.M. McKell (ed.), The biology and utilization of shrubs. Academic Press, London,

Naveh, Z. and J. Dan. 1973. The human degradation of Mediterranean landscapes in Israel, p. 373-390. In: F. Di Castri and H.A. Mooney, (eds.), Mediterranean-type ecosystems, origin and structure. SpringerVerlag, Berlin.

Ofer, Y. and N. Seligman. 1969. Fertilization of annual range in northern Israel. J. Range Manage. 22:337-341.

Olea, L., J. Paredes, and P. Verdasco. 1989. Characteristics productivas de los pastos de la dehesa del S.O. de la peninsula Iberica. II Reunion Iberica de Pastos y Forrajes, Badajoz-Elvas, pp. 147-172.

Olsen, S.R., C.M. Cole, F.S. Watanabe, and L.A. Dean. 1954. Estimation of 'Available' Phosphorus in Soils by Extraction with Sodium Bicarbonate. USDA Circ. 939.

Osman, A.E., P.S. Cocks, L. Russi, and M.A. Pagnotta. 1991. Response of Mediterranean grassland to phosphate and stocking rates: biomass production and botanical composition. J. Agr.. Sci., Camb. 116:37-46.

Rabinovich-Vin, A. 1979. Influence of parent rock on soil properties and composition of vegetation in the Galilee. Ph.D. thesis, The Hebrew Univ, of Jerusalem, Israel (in Hebrew).

Rossiter, R.C. 1966. Ecology of the Mediterranean annual type pasture. Adv. Agron. 18:1-56.

SAS. 1985. SAS User's Guide: Statistics. Version 5. SAS Inst., Inc., Cary, N.C.

Soil Survey Staff. 1975. Soil taxonomy. Basic system of soil classification for making and interpreting soil surveys. Handb. 436, USDA

Tagari, H., D. Levy, Z. Holzer, and D. Jean. 1976. Poultry litter for intensive beef production. Anim. Prod. 23:317-327.

Zohary, M. 1973. Geobotanical Foundations of the Middle East. Gustav Fischer Verlag, Stuttgart, and Swets \& Zeitlinger, Amsterdam.

\section{Literature Cited}

Bottomley, P.J. and M.B. Jenkins. 1983. Some characteristics of Rhizobium meliloti isolates from alfalfa fields in Oregon. J. Soil. Sci. Soc. Amer. 47:1,153-1,157.

Dan, J., D.H. Yaalon, H. Koyumdjisky, and Z. Raz. 1975. The soil association map of Israel (1:500,000). Div. of Scientific Publications, Agr. Res. Orgn, Bet Dagan, Israel. Pamphlet No. 147.

Dowling, D.N. and W.J. Broughton. 1986. Competition for nodulation of legumes. Ann. Rev. Microbiol. 40:131-157.

Feinbrun-Dothan, N. and A. Danin. 1991. Analytical flora of EretzIsrael. CANA, Publishing House Ltd., Jerusalem, Isracl.

Fresco, L.F.M., E. Hermans, and W. Vanderlans. 1984. Soil phosphorus as a factor controlling vegetation composition in a moist hayfield: a statistical evaluation of some methods for the determination of 'available' phosphate. Plant Soil, 78:259-269.

Henkin, Z., I. Noy-Meir, U. Kafkafi, M. Gutman, and N. Seligman. 1996. Phosphate fertilization primes production of rangeland on brown rendzina soils in the Galilee, Israel. Agr. Ecosyst. Environ. 59: 43-53.

Henkin, Z., I. Noy-Meir, U. Kafkafi, N. Seligman, and M. Gutman. 1994. Soil phosphorus in a managed Mediterranean woodland ecosystem: Herbage response and cattle grazing effect. Agr. Ecosyst. Environ. 47: 299-311.

Holzer, Z., J.G. Morris, M. Gutman, R. Benjamin, N.G. Seligman, and E. Bugin. 1986. Physiological criteria for improvement of production efficiency in beef cows subjected to nutritional and environmental "stress" due to fluctuating seasonal grazing conditions. Scientific Report, BARD Project No. 1-132-80, ARO, The Volcani Center, Bet Dagan, Israel.

Litav, M., G. Kupernik, and G. Orshan. 1963. The role of competition as a factor in determining the distribution of dwarf-shrub communities in the Mediterranean territory of Israel. J. Ecol. 51:467-480. 